\title{
Gendered geographies of violence: a multiple case study analysis of murdered women environmental defenders
}

\author{
Dalena Tran ${ }^{1}$ \\ Joan Martínez-Alier \\ Grettel Navas \\ Sara Mingorría \\ Universitat Autònoma de Barcelona, Catalonia, Spain
}

\begin{abstract}
This study illustrates how, despite the diversity of women environmental defenders and their movements around the world, there are near-universal patterns of violence threatening their survival. Violence against women environmental defenders, often perpetrated by government-backed corporations, remains overlooked. Research on this issue importantly contributes to discussions about environmental justice because women defenders make up a large proportion of those at the frontlines of ecological distribution conflicts. Through comparative political ecology, this research analyzes cases from the Environmental Justice Atlas, an online open-access inventory of environmental distribution conflicts, in which one or more women were assassinated while fighting a diverse array of extractive and polluting projects. Although the stories showcase a breadth of places, conflicts, social-class backgrounds, and other circumstances between women defenders, most cases featured multinational large-scale extractive companies supported by governments violently targeting women defenders with impunity.
\end{abstract}

Keywords: Violence, murder, women environmental defenders, EJAtlas, comparative political ecology

\section{Resumé}

Cette étude illustre comment, malgré la diversité des femmes défenseurs de l'environnement et de leurs mouvements à travers le monde, il existe des schémas de violence quasi universels qui menacent leur survie. La violence contre les femmes défenseurs de l'environnement, souvent perpétrée par des entreprises soutenues par le gouvernement, reste relativement invisible. Une telle question c'est une contribution importante aux discussions sur la justice environnementale car les femmes défenseurs représentent une grande partie tous ceux qui sont en première ligne de conflits de distribution environnementale. Parmit l'ecologie politique comparative cette recherche analyse des cas de l'Atlas de la Justice Environnementale, un inventaire en ligne à accès libre des conflits de distribution environnementale, dans lequel une ou plusieurs femmes ont été assassinées en combattant une variété de projets extractifs et polluants. Bien que les histoires mettent en évidence une multitude de lieux, de conflits, de classe sociale et d'autres circonstances entre les femmes défenseurs, la plupart des cas montrent des entreprises multinationales d'extraction soutenues par le gouvernement qui ciblent violemment des femmes dirigeantes en toute impunité.

Mots clés: Violence, meurtre, femmes défenseurs de l'environnement, EJAtlas, écologie politique comparée

\footnotetext{
${ }^{1}$ The authors are at Institut de Ciència i Tecnologia Ambientals (ICTA-UAB), Universitat Autònoma de Barcelona, 08193 Bellaterra (Cerdanyola del Vallès), Barcelona, Catalonia, Spain. E-mail dalenale.tran "at" e-campus.uab.cat. An early-stage Spanish draft was presented at the seminar on "Protection of biodiversity as a philosophical-legal problem", Universidad de Medellín (Colombia), March 18, 2017, reviewed in March 2018. Translated by Martha Moncada. This article is a spinoff of the initial draft and contributes many additional cases and insights. We dedicate this work to all women defenders fighting for environmental justice. Grettel Navas, Sara Mingorría, and Joan Martínez-Alier acknowlege support from the European Research Council for the EnvJustice project (GA 695446). Dalena Tran recieved support from "La Caixa" Foundation (ID 100010434). The fellowship code is LCF/BQ/DI19/11730049. Thankyou to referees and JPE editors.
} 


\section{Resumen}

Este estudio ilustra cómo, a pesar de la diversidad de las defensoras del medio ambiente y sus movimientos alrededor mundo, hay patrones universales de violencia que amenazan su supervivencia. La violencia contra las defensoras del medio ambiente por empresas extractivas, en colaboración con los gobiernos, sigue siendo relativamente invisible. Este tema contribuye importantemente a las discusiones sobre el extractivismo porque las activistas constituyen una gran proporción de las personas que están en la primera línea de los conflictos de distribución ecológica. Esta investigación analiza casos del Atlas de Justicia Ambiental, un inventario en línea de acceso abierto de conflictos de distribución ecológica, en el que una o más mujeres fueron asesinadas mientras luchaban contra diversos proyectos extractivos y contaminantes. Aunque las historias muestran una gran variedad de lugares, conflictos, clase social y otras circunstancias entre defensoras, la mayoría de los casos presentan conflictos creados por compañías multinacionales, respaldados por los gobiernos para imponer la extracción a gran escala y ejercer violencia contra mujeres defensoras en total impunidad.

Palabras clave: Violencia, asesinato, defensoras del medio ambiente, EJAtlas, ecología política comparada

\section{Introduction}

On March 2, 2016, news of woman environmental defender (henceforth WED) Berta Cáceres's assassination shocked the world, especially resonating within Latin America. Thousands of mourners followed the bearers carrying her coffin throughout the streets, holding up signs with her image forever remembering her as the protector of the Indigenous Lenca people against the Agua Zarca hydropower dam in Honduras. Silencing such a prominent activist is, in our view, part of a pattern of global violent repression against defenders in ecological distribution conflicts (henceforth EDCs) (Scheidel et al., 2020). EDCs refer to disputes arising from the unequal distribution of environmental benefits and costs of projects such as extractive industries, transport facilities, or waste dumping (Martinez-Alier and O'Connor, 1996). The origin of such conflicts is often unequal ecological exchange (UEE) (Hornborg, 1998). Some countries or communities within the same country are less or more privileged than others in the economic system, creating inequality from plundering resources and shifting the burdens to those with less power (Hornborg and Martinez-Alier, 2016). Furthermore, Martinez-Alier (1996) adds that such inequality often results from government-backed transnational corporations pursuing a capitalist model of economic development seeking rapid profit accumulation through large-scale over-exploitation of natural resources. Because no one willingly forfeits the land and water supporting their livelihoods, resources are often forcefully taken.

Current literature on EDCs is gradually bringing more attention to violence against environmental defenders (Butt et al., 2019; Del Bene, et al. 2018; Le Billon and Lujala, 2020; Navas et al., 2018; Scheidel et al., 2020). Yet little research addresses violence against WEDs, whose roles in environmental conflicts are still understudied and who are often simultaneously the most unnoticed and the worst impacted (Veuthey and Gerber, 2012; Martínez Alier and Navas, 2017; Deonandan and Bell, 2019). Furthermore, women are essential to environmental justice movements and global transformations as protectors of sustainability and community rights; they are not merely victims but rather political subjects able to transform and resist negative aspects of contemporary industrial practices (Bolados and Sánchez, 2017; Morgan, 2017; Katy, 2015). Such invisibility and vulnerability come from how WEDs additionally combat misogyny (Shiva, 1994; Veuthey and Gerber, 2012; Jenkins, 2017). As Paredes (2010) elaborates, women activists are often delegitimized based on their gender. Trying to enter public, political spaces for debate turns them into targets for multiple forms of violence. Murder is the most visible of these in environmental conflicts (Navas et al., 2018), but all threats to women defenders are difficult to document owing to intersecting marginalities and stakeholder interest in covering up abuses, as well as the fact that literature on violence in environmental conflicts does not separate data by gender (Deonandan and Bell, 2019).

It is imperative to fill this literature gap because, as Spivak (2010) argues, scholars must recognize the voices and leadership of the subaltern. Women defenders often remain voiceless. Abramovitz (1994) also states that knowledge is a form of power, and unless we improve documentation and understanding of womens' contributions to environmental movements, women will continue to remain unrecognized. Inspired by the legacies of Berta Cáceres and many other murdered WEDs, the following article presents the gruesome 
circumstances of assassinations of 35 WEDs around the world. The purpose of this exploratory study is not only to pay tribute to heroines often erased from history, but also to introduce and illustrate the understudied problem of violence against women environmental defenders. The argument is that the routine assassination of women environmental defenders reflects a distinctly gendered manifestation of violence in EDCs. Despite WEDs' diverse positionalities, circumstances, and advocacy methods, this gendered pattern of violence remains disturbingly universal. The novel contribution of this article to comparative political ecology is using many cases from diverse contexts to illuminate the politics shaping globally recurring patterns of violence against women in environmental conflicts. Whereas political ecology often follows in-depth analyses of case studies using ethnographic methods, we instead examine a global pattern in a multiple case study approach. Our research is a well-informed critique, empirically and analytically based on the EJAtlas and inviting deeper studies of environmental and gender justice. To do so, the study addresses the following questions: 1) Under which circumstances have women defenders been killed in environmental conflicts? 2) How were their circumstances similar and different across diverse geographies and sociopolitical contexts?

Section 2 presents feminist political ecology as the main theory informing data interpretation and the overall study. The next section, 3, explains the methods used to gather case studies, which are then listed in section 4 in a table and reviewed to reveal patterns of violence across diverse sociopolitical and geographical contexts. The article concludes by situating these findings in the larger global picture of repression and resistance in environmental conflicts.

\section{Theoretical framework}

One of the central influences informing this study is feminist political ecology (henceforth FPE). Whereas political ecology often remains within colonial spaces of knowledge production, FPE is distinct in its aims to render visible the often-overlooked situated knowledges and struggles, especially of those at the margins (Sultana, 2020; Elmhirst et al., 2017; Rocheleau et al., 1996). Although women and gender oppression are not its only focus, FPE does often concern a decolonization of gender as well as broader issues of social justice, wherein gender as well as class, race, sexuality, ability, age, and more are also central axes of difference across societies (Sultana, 2020). Applied to unequal resource access in environmental conflicts, FPE analyzes the uneven gendered power relations informing social phenomena such as gendered environmental knowledges, rights, and practices as well as gendered environmental movements (Rocheleau et al., 1996). Rocheleau et al. (1996), Elmhirst et al. (2017) and Bradshaw et al. (2017) elaborate that in patriarchal societies, expected performances of masculinity and femininity restrict men and women to gendered forms of labor and power, leading to differences in prioritizing and perceiving market intrusion and natural resource degradation. Agarwal for example, working in rural India, criticizes how analysts assume stereotypical perceptions of nature by women, and their roles in natural resource management and community politics, instead of investigating what women actually do and how they suffer (1992).

A FPE interpretation of violence against women in the context of extractive industrial activity also highlights gender oppression between male elites controlling and benefitting from extractivism. Violence occurs at multiple scales, asserting patriarchal power over women and the environment (Sultana, 2020). 'Disciplining dissent' refers to the violent punishment of women defenders, not only to exclude and repress them, but also its use as a political tactic controlling their bodies in gender-specific ways (Deonandan and Bell, 2019). For example, even when gender is not explicitly at issue, extractive industries and their supporters benefit and even rely on gender norms to support their projects. WEDs can be violently repressed for acting outside of sanctioned gender roles (Deonandan and Bell, 2019). Those hegemonic gender roles contribute to masculine domination over women in decision-making, mobilizations by women are frequently made more difficult because they havr to be balanced with their reproductive and social responsibilities. When mobilizations are organized, for example during environmental conflicts, they threaten the male-imposed status quo, which characterizes those projects. There is a lack of empirical research on violence against women in extractive conflicts (Bradshaw et al., 2017) and this study will draw upon FPE to highlight the uneven privileging and repression of diverse women who experience lethal violence in EDCs, tracing this to systemic patriarchal domination. 
Because the case study population used in this article includes women from around the world selected specifically for showcasing the diversity of their circumstances, attention must also be paid to intersectionality, another key concept in FPE. Intersectionality refers to how race, class, gender, sexuality, disability, age, education, location (rural versus urban), and other identifiers interact to create complex, overlapping, intersecting experiences of social structure, politics, and representation (Crenshaw, 2016). As central axes of difference across societies, such identities, when combined with other subject positions, create contextual, ambiguous, and coexisting differences of privilege and marginalization within interlocking systems of power and oppression. Intersectionality is important because mainstream feminism often homogenizes diverse women's experiences (Leopeng and Langa, 2020). Women of color, for instance, are especially subject to distinct forms of violence, silencing, and disempowerment. Being aware of the different layers of WEDs' identities is thus crucial to understanding the complexity of their positionalities beyond the often-fragmented general overviews or single case study analyses of 'women defenders' in current literature. The present study thus considers how intersectional differences of class, gender, race, and more create a more nuanced view of women defenders, their circumstances, and global patterns motivating their murders.

\section{Materials and methods}

This article analyzes 35 cases in which one or more WEDS were assassinated while fighting environmental injustices. The statistics of (different forms of) violence against environmental defenders are difficult to obtain, and there are no official UN statistics available. As generally acknowledged among researchers in the field, Global Witness and the EJAtlas are the best sources (Le Billon and Lujala, 2020), and we rely on them for our sample of killed WEDs. The cases were first recorded in detail in the Environmental Justice Atlas (EJAtlas), an online open-source inventory of EDCs (Temper et al., 2015, 2018; Martinez-Alier et al., 2016) with over 3,330 documented cases as of December 2020. To file EJAtlas cases, names of known assassinated WEDs were collected from secondary sources such as AWID's Women's Human Rights Defenders list, Global Witness's annual reports on assassinated HRDs, and Frontline Defender's records of violence against activists. The press often highlights isolated events that do not reflect the full extent of repression. More information was then compiled from sources such as news articles, blogs, videos, legal documents, and academic articles to flesh out a comprehensive report. EJAtlas cases are then moderated by ICTA-UAB researchers for quality and accuracy. An example is shown in Figure 1.

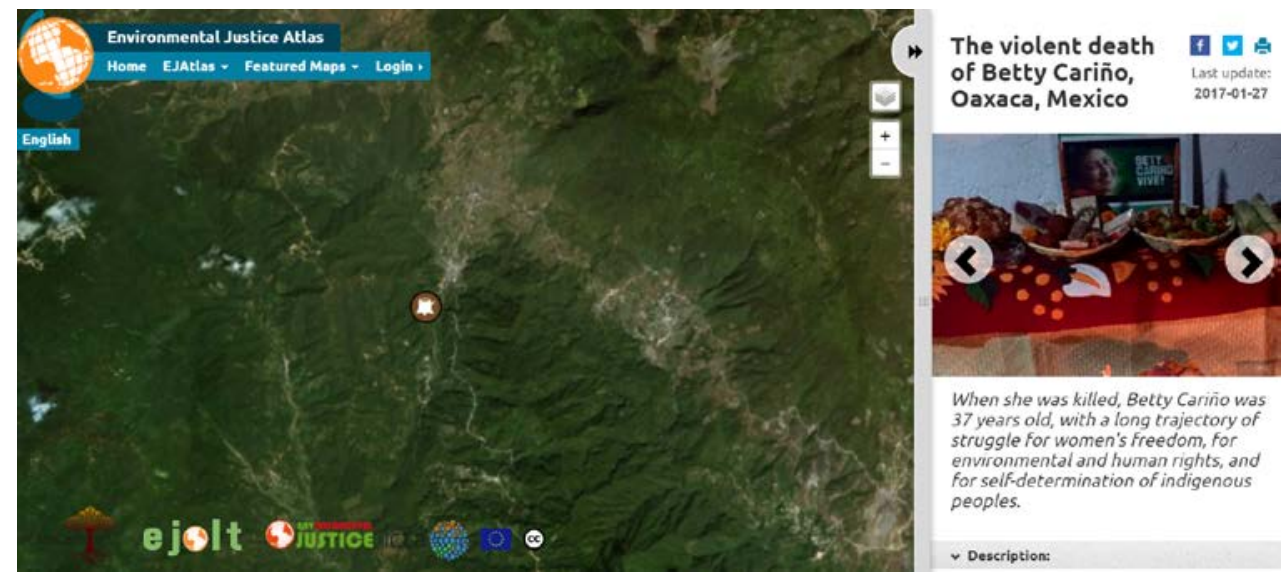

Figure 1: Example of EJAtlas activist entry page. Source: https://ejatlas.org/conflict/bettycarino-oaxaca-mexico

This article uses stricter definitions of murdered women environmental defenders than Global Witness, AWID, and other sources. Firstly, whereas these sources include land disputes and loosely-related causes as 
'environmental', this article only discusses EDCs in which accomplishing the movement's goals would improve some form of environmental degradation and/or redress environmental justice. Furthermore, we use the UNEP's definition of environmental defenders as those who act in personal or professional capacities to defend threats to the right to a clean and healthy environment (UNEP n.d.). Finally, women defenders in this study must have at least been suspected to have been killed for their activism rather than for other reasons.

The case studies are analyzed using comparative political ecology methods, which Taylor and Hurley (2016) explain as analyzing case studies from different regions together to better understand how similar outcomes can be produced across the globe in a wide variety of regional contexts. Comparative political ecology is useful because commonalities between diverse events or experiences are often difficult to see. These commonalities are important for highlighting recurring patterns in the behaviors of authorities and companies in enacting violence against women across time and space.

\section{Findings and discussion}

Table 1 is an overview of 35 cases of WEDs likely assassinated for their environmental advocacy. These cases are a small sample of the unknown number of all killed WEDs. Further investigation of cases already recorded in the EJAtlas and other sources on killed environmental defenders (women and men) (Scheidel et al., 2020) could increase the sample to a few hundred cases. However, our sample still showcases the diversity of these heroines, indicating that there is no homogenous WED archetype because every individual and every conflict has contextual particularities. While many WED killed fit into the category of "the environmentalism of the poor and the Indigenous" as will be further elaborated upon below (Martinez-Alier, 2002), others in our sample were conservationists preserving a notion of nature without people. The cases were selected for being notable, diverse examples of deadly EDCs common to their respective contexts, though there are many more conflicts showing similar evidence for global patterns of violence beyond the scope of this study and current documentation in EJAtlas and other databases. Case summaries for each of the WEDs are available in the Appendix.

\begin{tabular}{|c|c|c|c|c|c|c|}
\hline \multicolumn{7}{|c|}{ Africa (10 WEDs) } \\
\hline WEDs + links & Location & Conflict & Race* & Occupation & Violences & Outcomes \\
\hline $\begin{array}{l}\text { Dian Fossey, } \\
\text { mobilization } \\
\text { leader }\end{array}$ & Rwanda & Conservation & White & Researcher & $\begin{array}{l}\text { Death threats, } \\
\text { burglary, } \\
\text { machete attack }\end{array}$ & $\begin{array}{l}\text { Crime } \\
\text { unresolved, } \\
\text { conservation } \\
\text { success }\end{array}$ \\
\hline $\begin{array}{l}\frac{\text { Fikile }}{\text { Ntshangase, }} \\
\text { mobilization } \\
\text { leader }\end{array}$ & South Africa & Mining & Black & Activist & Shot by hitmen & $\begin{array}{l}\text { Crime and } \\
\text { conflict } \\
\text { unresolved }\end{array}$ \\
\hline $\begin{array}{l}\text { Ilaria Alpi, } \\
\text { independent } \\
\text { activist }\end{array}$ & Somalia & $\begin{array}{l}\text { Waste } \\
\text { dumping }\end{array}$ & White & Journalist & Shot by hitmen & $\begin{array}{l}\text { Crime and } \\
\text { conflict } \\
\text { unresolved }\end{array}$ \\
\hline $\begin{array}{l}\text { Joan Root, } \\
\text { mobilization } \\
\text { leader }\end{array}$ & Kenya & Overfishing & White & Filmmaker & $\begin{array}{l}\text { Burglary, death } \\
\text { threats, shot by } \\
\text { hitmen }\end{array}$ & $\begin{array}{l}\text { Crime and } \\
\text { conflict } \\
\text { unresolved }\end{array}$ \\
\hline $\begin{array}{l}\frac{\text { Kananwa }}{\text { Sibomana, Ila }} \\
\text { Muranda, } \\
\text { Rachel } \\
\text { Masika; group } \\
\text { members }\end{array}$ & $\begin{array}{l}\text { Congo } \\
\text { (DRC) }\end{array}$ & Conservation & Black & Rangers & $\begin{array}{l}\text { Attacks, killed } \\
\text { by bandits }\end{array}$ & $\begin{array}{l}\text { Crime and } \\
\text { conflict } \\
\text { unresolved }\end{array}$ \\
\hline
\end{tabular}




\begin{tabular}{|c|c|c|c|c|c|c|}
\hline $\begin{array}{l}\text { Musu Conteh, } \\
\text { unnamed } \\
\text { woman; } \\
\text { group } \\
\text { members }\end{array}$ & Sierra Leone & Mining & Black & Miner & Shot by police & $\begin{array}{l}\text { Crime and } \\
\text { conflict } \\
\text { unresolved }\end{array}$ \\
\hline $\begin{array}{l}\text { Unnamed } \\
\text { woman; group } \\
\text { member }\end{array}$ & Nigeria & Oil refining & $\begin{array}{l}\text { Black, } \\
\text { Indigenous }\end{array}$ & Farmer & Shot by police & $\begin{array}{l}\text { Crime and } \\
\text { conflict } \\
\text { unresolved }\end{array}$ \\
\hline \multicolumn{7}{|c|}{ Asia (10 WEDs) } \\
\hline WEDs + links & Country & Conflict & Race* & Occupation & Violences & Outcomes \\
\hline $\begin{array}{l}\frac{\text { Aysin }}{\text { Büyüknohutçu }} \\
\text { independent } \\
\text { activist }\end{array}$ & Turkey & Mining & & Farmer & Shot by hitmen & $\begin{array}{l}\text { Crime } \\
\text { unresolved, } \\
\text { project } \\
\text { stopped }\end{array}$ \\
\hline $\begin{array}{l}\frac{\text { Gerlie }}{\text { Menchie, }} \\
\text { group member }\end{array}$ & Philippines & Overfishing & & Secretary & $\begin{array}{l}\text { Death threats, } \\
\text { shot by hitmen }\end{array}$ & $\begin{array}{l}\text { Crime and } \\
\text { conflict } \\
\text { unresolved }\end{array}$ \\
\hline $\begin{array}{l}\text { Gloria } \\
\text { Capitán, } \\
\text { mobilization } \\
\text { leader }\end{array}$ & Philippines & Coal power & & $\begin{array}{l}\text { Karaoke bar } \\
\text { owner }\end{array}$ & Shot by hitmen & $\begin{array}{l}\text { Crime and } \\
\text { conflict } \\
\text { unresolved }\end{array}$ \\
\hline $\begin{array}{l}\text { Karunamoyee } \\
\text { Sardar, } \\
\text { mobilization } \\
\text { leader }\end{array}$ & Bangladesh & Aquaculture & & Farmer & $\begin{array}{l}\text { Death threats, } \\
\text { shot by hitmen }\end{array}$ & $\begin{array}{l}\text { Crime and } \\
\text { conflict } \\
\text { unresolved, } \\
\text { project } \\
\text { blocked }\end{array}$ \\
\hline $\begin{array}{l}\frac{\text { Montha }}{\text { Chukaew, }} \\
\underline{\text { Pranee }} \\
\underline{\text { Boonrat; }} \\
\text { mobilization } \\
\text { leaders }\end{array}$ & Thailand & Agriculture & & Activists & Shot by hitmen & $\begin{array}{l}\text { Crime and } \\
\text { conflict } \\
\text { unresolved }\end{array}$ \\
\hline $\begin{array}{l}\frac{\text { Nasreen }}{\text { Pervin, group }} \\
\text { member }\end{array}$ & Bangladesh & Mining & & Activist & $\begin{array}{l}\text { Legal } \\
\text { harassment, car } \\
\text { crash }\end{array}$ & $\begin{array}{l}\text { Crime } \\
\text { unresolved, } \\
\text { project } \\
\text { stopped }\end{array}$ \\
\hline $\begin{array}{l}\text { Shehla } \\
\text { Masood, } \\
\text { mobilization } \\
\text { leader }\end{array}$ & India & Mining & & Activist & $\begin{array}{l}\text { Death threats, } \\
\text { legal } \\
\text { harassment, shot } \\
\text { by hitmen }\end{array}$ & $\begin{array}{l}\text { Crime and } \\
\text { conflict } \\
\text { unresolved }\end{array}$ \\
\hline $\begin{array}{l}\frac{\text { Teresita }}{\text { Navacilla, }} \\
\text { mobilization } \\
\text { leader }\end{array}$ & Philippines & Mining & Indigenous & $\begin{array}{l}\text { Small } \\
\text { business } \\
\text { owner }\end{array}$ & $\begin{array}{l}\text { Death threats, } \\
\text { shot by hitmen }\end{array}$ & $\begin{array}{l}\text { Crime and } \\
\text { conflict } \\
\text { unresolved }\end{array}$ \\
\hline $\begin{array}{l}\text { Valsa John, } \\
\text { mobilization } \\
\text { leader }\end{array}$ & India & Mining & & Nun & Shot by hitmen & $\begin{array}{l}\text { Crime and } \\
\text { conflict } \\
\text { unresolved }\end{array}$ \\
\hline
\end{tabular}




\begin{tabular}{|c|c|c|c|c|c|c|}
\hline \multicolumn{7}{|c|}{ Latin America (10 WEDs) } \\
\hline WEDs + links & Country & Conflict & Race* & Occupation & Violences & Outcomes \\
\hline $\begin{array}{l}\text { Alberta } \\
\text { Cariño, } \\
\text { mobilization } \\
\text { leader }\end{array}$ & Mexico & Hydropower & Indigenous & Farmer & $\begin{array}{l}\text { Legal } \\
\text { harassment, } \\
\text { death threats, } \\
\text { shot by hitmen }\end{array}$ & $\begin{array}{l}\text { Crime and } \\
\text { conflict } \\
\text { unresolved }\end{array}$ \\
\hline $\begin{array}{l}\text { Adelinda } \\
\text { Gómez, } \\
\text { mobilization } \\
\text { leader }\end{array}$ & Colombia & Mining & & $\begin{array}{l}\text { Multiple } \\
\text { part-time } \\
\text { jobs }\end{array}$ & $\begin{array}{l}\text { Death threats, } \\
\text { shot by hitmen }\end{array}$ & $\begin{array}{l}\text { Crime and } \\
\text { conflict } \\
\text { unresolved }\end{array}$ \\
\hline $\begin{array}{l}\text { Berta Cáceres, } \\
\text { mobilization } \\
\text { leader }\end{array}$ & Honduras & Hydropower & Indigenous & Teacher & $\begin{array}{l}\text { Death threats, } \\
\text { legal } \\
\text { harassment, shot } \\
\text { by hitmen }\end{array}$ & $\begin{array}{l}\text { Crime } \\
\text { unresolved, } \\
\text { project } \\
\text { funding } \\
\text { revoked }\end{array}$ \\
\hline $\begin{array}{l}\text { Dorothy } \\
\text { Stang, } \\
\text { mobilization } \\
\text { leader }\end{array}$ & Brazil & Logging & White & Nun & $\begin{array}{l}\text { Death threats, } \\
\text { shot by hitmen }\end{array}$ & $\begin{array}{l}\text { Hitmen } \\
\text { jailed, } \\
\text { conflict } \\
\text { unresolved } \\
\end{array}$ \\
\hline $\begin{array}{l}\text { Guadalupe } \\
\text { Campanur, } \\
\text { mobilization } \\
\text { leader }\end{array}$ & Mexico & Logging & Indigenous & Ranger & $\begin{array}{l}\text { Kidnapping, } \\
\text { rape }\end{array}$ & $\begin{array}{l}\text { Crime and } \\
\text { conflict } \\
\text { unresolved }\end{array}$ \\
\hline $\begin{array}{l}\text { Jeannette } \\
\text { Kawas, } \\
\text { mobilization } \\
\text { leader }\end{array}$ & Honduras & Conservation & & Accountant & Shot by hitmen & $\begin{array}{l}\text { Crime and } \\
\text { conflict } \\
\text { unresolved }\end{array}$ \\
\hline $\begin{array}{l}\text { Kimberley } \\
\text { Blackwell, } \\
\text { independent } \\
\text { activist }\end{array}$ & Costa Rica & Conservation & White & $\begin{array}{l}\text { Artisan } \\
\text { chocolatier }\end{array}$ & $\begin{array}{l}\text { Death threats, } \\
\text { attacks, } \\
\text { strangling }\end{array}$ & $\begin{array}{l}\text { Crime and } \\
\text { conflict } \\
\text { unresolved }\end{array}$ \\
\hline $\begin{array}{l}\text { Laura Leonor, } \\
\text { mobilization } \\
\text { leader; } \\
\text { Merilyn } \\
\text { Topacio, } \\
\text { group member }\end{array}$ & Guatemala & Mining & Indigenous & $\begin{array}{l}\text { Small } \\
\text { business } \\
\text { owner and } \\
\text { high school } \\
\text { student }\end{array}$ & $\begin{array}{l}\text { Military attack, } \\
\text { shot by hitmen, } \\
\text { death threats, } \\
\text { legal harassment }\end{array}$ & $\begin{array}{l}\text { Crime } \\
\text { unresolved, } \\
\text { project } \\
\text { stopped } \\
\text { temporarily }\end{array}$ \\
\hline $\begin{array}{l}\text { Macarena } \\
\text { Valdés, } \\
\text { mobilization } \\
\text { leader }\end{array}$ & Chile & Hydropower & & Teacher & $\begin{array}{l}\text { Legal } \\
\text { harassment, } \\
\text { military attack, } \\
\text { hanging }\end{array}$ & $\begin{array}{l}\text { Crime and } \\
\text { conflict } \\
\text { unresolved }\end{array}$ \\
\hline
\end{tabular}




\begin{tabular}{|c|c|c|c|c|c|c|}
\hline \multicolumn{7}{|c|}{ North America and Europe (5 WEDs) } \\
\hline WEDs + links & Country & Conflict & Race* & Occupation & Violences & Outcomes \\
\hline $\begin{array}{l}\text { Gladys del } \\
\text { Estal, group } \\
\text { member }\end{array}$ & Spain & Nuclear power & White & $\begin{array}{l}\text { College } \\
\text { student }\end{array}$ & Shot by police & $\begin{array}{l}\text { Lenient } \\
\text { prison } \\
\text { sentence, } \\
\text { project } \\
\text { stopped, } \\
\text { moratorium }\end{array}$ \\
\hline $\begin{array}{l}\text { Hilda Murrell, } \\
\text { group member }\end{array}$ & England & Nuclear power & White & Botanist & $\begin{array}{l}\text { Death threats, } \\
\text { military } \\
\text { surveillance, } \\
\text { rape, stabbing } \\
\end{array}$ & $\begin{array}{l}\text { Crime and } \\
\text { conflict } \\
\text { unresolved }\end{array}$ \\
\hline $\begin{array}{l}\text { Jane Tipson, } \\
\text { mobilization } \\
\text { leader }\end{array}$ & Saint Lucia & Conservation & White & $\begin{array}{l}\text { Restaurant } \\
\text { owner }\end{array}$ & Shot by hitmen & $\begin{array}{l}\text { Crime and } \\
\text { conflict } \\
\text { unresolved }\end{array}$ \\
\hline $\begin{array}{l}\text { Karen } \\
\underline{\text { Silkwood, }} \\
\text { mobilization } \\
\text { leader }\end{array}$ & $\begin{array}{l}\text { United } \\
\text { States }\end{array}$ & Nuclear power & White & Technician & $\begin{array}{l}\text { Death threats, } \\
\text { legal } \\
\text { harassment, car } \\
\text { crash }\end{array}$ & $\begin{array}{l}\text { Crime } \\
\text { unresolved, } \\
\text { project } \\
\text { stopped }\end{array}$ \\
\hline $\begin{array}{l}\frac{\text { Kateryna }}{\text { Handziuk, }} \\
\text { independent } \\
\text { activist }\end{array}$ & Ukraine & Logging & White & Politician & $\begin{array}{l}\text { Legal } \\
\text { harassment, } \\
\text { death threats, } \\
\text { acid attack }\end{array}$ & $\begin{array}{l}\text { Lenient } \\
\text { prison } \\
\text { sentence, } \\
\text { conflict } \\
\text { unresolved }\end{array}$ \\
\hline
\end{tabular}

Table 1: Overview of WEDs. *Race left blank when the woman was of the titular, "mainstream" ethnic group of the nation she was from without distinct marginalizations or privileges from being black/Indigenous/person of color (BIPOC) or white. Information on race is taken directly from how the women are described in news articles from EJAtlas case source material.

\section{An intersectional breakdown of regional disparities}

Most notably, even when combined, North America and Europe only include five cases compared to the ten showcased for every other region. This discrepancy also corresponds to the proportions of environmental defenders (men and women) killed by continent (for instance, as recorded by Global Witness). Frequencies might also reflect the uneven burdens and silencing of women worldwide depending on not only regional context, but also intersectional power disparities between certain female demographics. Consequently, much fewer cases of women defender assassinations are reported in countries benefiting from extractivism, versus countries exporting extractivist goods and labor.

Firstly, considering contexts, more information is available about WED killings in Latin America and Southeast Asia compared to Africa owing perhaps to differences in reporting culture. Subsequently, there were an abundance of possible cases to select from, making the Latin American and Asian cases a more diverse and inclusive sample of possible types of cases than those for Africa, which were difficult to find and thus had less to choose from. As Global Witness (2019) explains, variance in political tolerance toward civil society organizations and journalists documenting attacks means that depending on region, not only are there fewer strong networks of contacts, but there is also less ability to speak out without brutal consequences. Rural and urban divides also mean there is weaker information exchange between existing groups, causing difficulty in obtaining evidence from many African countries. There may additionally be less murder cases to report on in North America and Europe as countries benefitting from extractivism elsewhere owing to various factors, such as a difference in governance practices compared to regions that may have more authoritatian regimes enabling 
widespread armed conflict and criminal impunity as well as there being fewer EDCs and resulting resource conflicts in their own countries (Butt et al., 2019; Le Billon and Lujala, 2020; Temper et al., 2015; Scheidel et al., 2020).

Secondly, a feminist political ecology understanding of regional variance in reporting WED deaths reveals how their intersectionally differing circumstances were affected by uneven power relations between diverse women. White women are overrepresented among African and North American/European cases despite BIPOC (black/Indigenous/people of color) shouldering more of the burden in EDCs to mobilize and bear consequences, as is reflected in the listed cases (AWID, 2017). BIPOC women are perhaps excluded from public debate because their involvement in environmental protests is grounded in their experiences of racial discrimination (Bullard, 1990; Krauss, 1993). The same may also apply to those in extractivist exporter countries, whose marginality exposing them to EDCs in the first place means they have little power to control and criticize the discourse. Meanwhile, white women, who typically are not victims of systemic discrimination, have an entirely different relationship with governments or formal organizations, having more leverage to raise their voices (Krauss, 1993; Joshi et al., 2020; Sultana, 2020). Indeed, white ecofeminists have also long been criticized for the appropriation and erasure of their nonwhite peers' knowledge and experiences, taking up much of the space for debate (Agarwal, 1992; Buckingham and Kulcur, 2009). In contrast, violence against and murders of women of color are normalized in contexts where their lives are treated as disposable and their environmental justice contributions are undervalued (England, 2018; Gqola, 2007). Subsequently, as the listed cases reflect, murders of white WEDs often overshadow deaths of their BIPOC peers not only because they had more reputation, but also because their deaths were considered more newsworthy. This is evident among the African cases, where the white women achieved celebrity status before and even more so after death, as every single one of them had documentaries or even movies made in their honor. Meanwhile, cases of lethal violence against black women were much more obscure, and sometimes not even their names are recorded; they were just another fatality of routinized killings. Further research with larger samples of WED killed might confirm such hypotheses.

\section{The role of status in WED advocacy and its diverse manifestations}

Political ecology discourse often theorizes environmental justice advocacy as stemming from environmentalism of the poor (and the Indigenous), which Martinez-Alier (2002, 2013) explains as everyday (often impoverished or otherwise vulnerable) people being motivated to resist extractive projects by governments and corporations, which disproportionately use resources and directly harm the land and water their livelihoods depend on. This is a counternarrative to other schools of environmental thought positioning upper and middle-class people as more environmentally conscious owing to their "modern" efficiency and knowledge whereas the "underdeveloped" poor are responsible for environmental degradation. A feminist political ecology interpretation of WED mobilizations, however, further complicates the debate because not all the defenders could be cleanly categorized as either peasants protecting their own land or as saviors enlightening people toward better environmental practices. Their movements were diverse, and though some are similar enough to loosely group together, there are always exceptions. Advocacy in the sample ranged from defending livelihoods, the environment, and wildlife from mining, fossil fuels, hydroelectric projects, nuclear power, logging, waste dumping, poaching, fishing, environmental degradation for infrastructure construction, and more. All the cases have therefore in common the "materiality" of the origins of the conflict, but they respond to different strands in the global environmental movement, namely some belong more to "conservationism" and some belong to "the environmentalism of the poor and the Indigenous."

Among the listed WEDs, twenty, more than half of the total, were Indigenous peasants or low-income women with informal or blue-collar jobs. As with the environmentalism of the poor, logging, mining, agribusiness, fishing, and hydroelectric conflicts often occurred on their lands or in their territories, necessitating struggle against transnational corporations in countries promoting extractivism, mostly involving Indigenous or local leaders. Movements against logging, mining, agribusiness, fishing, dams, and conservation often used protests or blockades as their main strategy, often also in combination with legal retaliation such as petitions or filing claims against companies violating ILO Convention 169 protecting Indigenous peoples' right 
to informed and prior consent. Peasant WEDs such as Cariño, Conteh, Sardar, and the unnamed women especially resorted to putting their bodies on the line at protests and dying in action. This is a reflection of how much they struggled to have their voices heard not just as environmentalists, but as people at the intersection of marginalities emanating from their status as poor women of color. Some (like the two nuns murdered, one in Brazil and one in India) were not peasants, but they were ready to sacrifice themselves for poor rural peoples. We could easily expand the list of WED killed already recorded in the EJAtlas in Latin America on the side of the "environmentalism of the poor" - for instance, in Brazil, Nicinha was a leader of the MAB fighting for the rights of the people displaced by the Jirau dam near Porto Vlho, denouncing the effects of the dam on fishing activity in the Madeira River. She was killed on January 7, 2016. Additionally, in Brazil, illegal logging and land grabbing led to the deaths of well-known environmental defenders Zé Claudio and Maria do Espirito Santo in Pará, in 2011.

On the other hand, some murdered WEDs were middle-class or well-off, ten held degrees (even multiple masters or PhDs), and some like Root were celebrities. For instance, Blackwell, Stang, Tipson, Root, Fossey, and Alpi were white defenders from the North who used their privilege to fight injustices observed in the places they relocated to, defending communities they were not born into. Those fighting against nuclear power were also white, educated women, reflecting the growing nuclear industry in wealthy countries in the 1970s and 1980s. The nuclear, waste dumping, and conservation cases in this study focused more on legal action or exposure of corruption over physical protests, though the Sizewell B movement did have protests that Murrell could not participate in before her murder and Gladys del Estal's antinuclear involvement was mainly through protest. Tipson, Root, Fossey, and Blackwell were white women who moved to commodity frontiers and promoted conservationism. Their relative privilege is reflected in their advocacy tactics having less of a grassroots protest movement approach. As white women, they had different tools, literacies, and voices at their disposal to navigate formal courses of action in legal, professional, and public spheres. However, they were all critical of the "development" projects they witnessed causing injustices. Thus, Nawas in Honduras was killed while defending nature and also the local Indigenous Garifuna people.

One outlier to the class narrative was Handziuk, who focused on legal action and corruption exposure on behalf of her own people as a defender, using her political power to incite action against a corrupt corporation and a government that was targeting vulnerable communities. Silkwood, meanwhile, did not have as much clout as a blue-collar worker yet still sought to confront a corporation harming her community much in the way "environmentalism of the poor" manifests elsewhere. Gómez_and Valdés also did not fit any mold as professional and educated experts working within their home countries, but socially they were outsiders sympathizing with Indigenous groups they personally were not members of. An intersectional analysis thus illuminates the somewhat unpredictable nature of WED advocacies in that while many did follow the environmentalism of the poor and Indigenous peoples, women defenders do not face a homogenous, or even form of marginalization. Their diverse positionalities and circumstances interacted to create complex interactions between the various facets of who they are and what they fought for, evident in which mobilization strategies were available to differently and simultaneously privileged -yet alienated - women.

\section{Diverse women versus universal violence}

Although the cases in the article encompass a breadth of places, conflicts, and circumstances, there are several key similarities revealing a universal pattern of violence. Almost all WEDs founded or took part in environmental justice organizations often allied with larger networks. They struggled not only against the project they were killed for, but also other ongoing projects and exploitation. Most cases also featured conflicts against multinational companies, while in some cases, they were local but still served the global market (domestic companies and bandits exporting to the Global North). In every case, these operations are backed by governments to impose large-scale extraction for capitalist profit accumulation. The cases in this article support Glazebrook and Opoku's (2018) findings that governments often do not hold international stakeholders accountable for their environmental and human rights violations, despite criminalizing defenders. "Corporate social irresponsibility" and a lack of liability are the rules rather than the exceptions. In line with patterns of unequal ecological distribution (Hornborg, 1998), these WEDs thus struggled against the disproportionate 
burden shouldered for those more powerful in a capitalist system. Whether the female leaders were poor or not themselves, their advocacy very often reflects an environmentalism of the poor (Martinez-Alier, 2002) because the communities they defended had their resources and land forcefully taken, exploited, and degraded by corporations and states. Moreover, the killers were almost always hired assassins. The murderers usually go unpunished, but those convicted for their crimes increase case visibility.

FPE readings of these cases also reveal gender-specific violence underlying the overall circumstances behind each conflict. As with disciplined dissent, all violent targeting, explicitly gender-specific or not, occurred within contexts that marginalizing each defender and undermining her (and her movement's) capacity to keep fighting by deeming them terrorists, making their duties as mothers and grandmothers more difficult and riskier, obstructing justice, and in many other ways (Deonandan and Bell, 2019). It is well-documented that women are much more vulnerable and aware of EDC consequences to begin with, owing to a gendered division of labor, unequal power distribution, as well as moral and behavioral expectations (Arora-Jonsson, 2011; Peek, 2007; Agarwal, 1992). On top of the barriers WEDs already face as stewards for vulnerable communities, gender repression also hinders their efforts, manifesting in gendered physical violence such as the rapes of Campanur and Murray as well as discursive violence - such as with Masood, alleged to be a 'seductress.'

This was particularly salient for the unnamed woman killed during protests against Chevron in Nigeria. The case itself is a classic example of an EDC, as Chevron wrought havoc on the land and livelihoods of villagers in Escravos, who did not receive economic benefits from their industrial scale oil activities in return. Yet a closer FPE examination reveals that the EDC unevenly affected women, who were additionally devastated by the environmental degradation that prevents their subsistence activities as well as being victim to the forced prostitution, rapes, and other physically violent abuses that arrived with the industrial workforce, and then later with the police brutality against their protests. Chevron could commit such injustices in the first place owing to "male deals" that village men made with the companies without consent from women, whose knowledge and awareness of consequences were dismissed first during consultation and again when making demands to Chevron. These distinct forms of gendered violence and silencing are thus a direct result of the complex interactions between uneven power relations, different knowledges, and more that come with gender role expectations, especially for multiply marginalized women (Elmhirst et al., 2017; Rocheleau et al., 1996; Sultana, 2020).

An intersectional view also does not neglect that, as women, they were all subject to marginality and its subsequent disturbingly universal patterns of violence against WEDs, they did not experience such marginality in the same way (Leopeng and Langa, 2020). Such a diverse pool of women and contexts indeed had varying levels of privilege that affected how they could intervene in EDCs and how people in turn reacted to them. For instance, this is notable among WEDs who were not always unambiguously "right", sometimes even enacting violence themselves. Examples include the Virunga rangers and "green militarism", Fossey and Blackwell's hostility toward some humans, and Root's Task Force that worsened corruption. In each of these cases, the WEDs had a position of leverage above ordinary people. The Virunga rangers in the Congo were employees of a paramilitary initiative infringing upon Indigenous rights while also ambiguously claiming to defend them through the conservation of the land that Indigenous lives depended on. Fossey, Blackwell, and Root, white wealthy conservationists, used their privilege to establish programs meant to help communities and wildlife, yet their well-intentioned actions were also their downfall as outsiders whose privilege also meant they were at times insensitive or ill-advised in inadvertedly enacting or enabling violence themselves rather than breaking or criticizing cycles of violence altogether. Meanwhile, there were also peasant Indigenous WEDs who were widely ridiculed, yet other fellow peasant Indigenous women who were celebrated as underdog heroes of their people; such polarizing receptions could coexist even for the same woman. All these different manifestations of direct as well as discursive violence were still, however, ultimately drawing from the same universal patterns enabling violence against WEDs at multiple scales. 


\section{Conclusion}

Across unique contexts worldwide, Women Environmental Defenders have mobilized using an abundant combination of strategies, and in collaboration with diverse networks, towards implementing their own ideas of environmental justice. Our results show that violence against WEDs is not always motivated by sheer necessity (as it is with an "environmentalism of the poor"), but rather there is a variety of motivations, as shaped by and also transcending different positionalities of class, race, and more. Yet WEDs continue to be routinely raped, beaten, shot, strangled, hit by cars, and sliced to death to prevent them from exposing and shutting down collaboration between states, corporations, and criminal elements that facilitate ecological degradation. Each story points to the tenacity of women at the frontlines, despite intersectionally experienced barriers. The cases showcase the severe forms of violence that female environmentalists suffer. For each woman killed, there are presumably many more who are wounded and many more who are displaced and threatened. Violence often succeeds in dismantling WED-led movements through targeted killing to alarm others into choking on their words. While many studies in political ecology limit their scope to one or a few cases, this article's comparative analysis of multiple case studies across various regions is critical to current work on environmental conflicts because the 35 diverse stories come together to reveal a pattern of violence universal across time, space, and circumstance, embedded in geographies of land, resources, and communities.

Given that the stories in this article represent just a small sample of a vast unknown, the point is not to offer a closed typology of women defenders. Instead, this research showcases not only how diverse their movements can be, but also emphasizes how despite the range of circumstances in each case, there were still the same disturbing patterns of global capitalist and patriarchal violence in each story. These are the systematic issues that we need to address. None of these WEDs wanted to die, but they were acutely aware of the need to set an example, giving up their lives for the sake of their communities and the environment. For each activist killed, how many are injured? How many are scared into submission, and how many disappear? How many go into hiding, and how many are discouraged from further protest or advocacy for the rest of their lives? There is no need for repression where activism has ceased because of fear. Just some examples of women singled out in wider campaigns of violence include Gloria Ushigua Santi or Wendy Mutegi, Indigenous women in Ecuador and Kenya respectively, who have been brutally beaten for their advocacy but not defeated (Tran, 2021a). A broader campaign of discursive violence against women occurs in places such as South Africa, where WEDs struggle to have their voices heard and to be taken seriously beyond homogenizing, harmful stereotypes (Tran, 2021b). As such, no matter how diverse these 35 cases were, the fact that each death followed from the same global patterns of exploitation, extortion, and extermination mean that it is more critical than ever to question the corporate activity that we are complicit with every day, and to increase the visibility of those risking everything to open our eyes.

\section{References}

Abramovitz, J. (1994). Biodiversity and gender issues: Recognizing common ground. In Harcourt, W. (Ed.) Feminist perspectives on sustainable development. Zed.

Agarwal, B. (1992). The gender and environment debate: Lessons from India. Feminist Studies, 18(1), 199158.

Arora-Jonsson, S. (2011). Virtue and vulnerability: Discourses on women, gender and climate change. Global Environmental Change, 21(2), 744-751.

AWID (2017). Confronting extractive industries. Retrieved December 21, 2020, from

https://www.awid.org/sites/default/files/atoms/files/whrds-confronting extractive industries reporteng.pdf

Birkeland, J. (1993). Towards a new system of environmental governance. The Environmentalist, 13(1), 1932.

Bolados, P., \& Sánchez, A. 2017. Una ecología política feminista en construcción: El caso de las 'mujeres de zonas de sacrificio en resistencia', Región de Valparaíso, Chile. Psicoperspectivas Individuo y Sociedad 16(2), 33-42. 
Bradshaw, S., Linneker, B., \& Overton, L. (2017). Extractive industries as sites of supernormal profits and supernormal patriarchy? Gender and Development, 25(3), 439-454.

Buckingham, S., \& Kulcur, R. (2009). Gendered geographies of environmental injustice. Antipode, 41(4), 659683.

Butt, N., Lambrick, F. \& Menton, M. (2019). The supply chain of violence. Nature Sustainability, 2, $742-747$.

Crenshaw, K. (2016). Mapping the margins: Intersectionality, identity politics, and violence against women of color. Stanford Law Review, 43(6), 1241-1299.

Del Bene, D., Schneidel, A., \& Temper, L. (2018). More dams, more violence? A global analysis on resistances and repression around conflictive dams through co-produced knowledge. Sustainability Science, 13(3), 617-633.

Deonandan, K. \& Bell, C. (2019). Discipline and punish: gendered dimensions of violence in extractive development. Canadian Journal of Women and the Law, 31(1), 24-57.

Elmhirst, R., Siscawati, M., Basnett, B., Ekowati, D. (2017). Gender and generation in engagements with oil palm in East Kalimantan, Indonesia: Insights from feminist political ecology. The Journal of Peasant Studies, 44(6), 1135-1157.

England, S. (2018). Writing terror on the bodies of women: Media coverage of violence against women in Guatemala. Lexington Books.

Glazebrook, T. \& Opoku, E. (2018). Defending the defenders: Environmental protectors, climate change and human rights. Ethics and the Environment, 23(2), 83-109.

Global Witness. (2019). Enemies of the State? Retrieved April 9, 2020 from https://www.globalwitness.org/documents/19766/Enemies of the State.pdf

Gqola, P. D. (2007). How the 'cult of femininity' and violent masculinities support endemic gender based violence in contemporary South Africa. African Identities, 5(1), 111-124.

Hornborg, A. (1998). Towards an ecological theory of unequal exchange: Articulating world system theory and ecological economics. Ecological Economics, 25(1), 127-136.

Hornborg, A. \& Martinez-Alier, J. (2016). Ecologically unequal exchange and ecological debt. Journal of Political Ecology 23(1), 328-333. https://doi.org/10.2458/v23i1.20220

Jenkins, K. (2015). Unearthing women's anti-mining activism in the Andes: Pachamama and the "Mad Old Women". Antipode, 47(2), 442-460.

Jenkins, K. (2017). Women anti-mining activists' narratives of everyday resistance in the Andes: staying put and carrying on in Peru and Ecuador. Journal of Gender, Place, and Culture, 24(1), 1441-1459.

Joshi, D. K., Hailu, M. F., \& Reising, L. J. (2020). Violators, virtuous, or victims? How global newspapers represent the female member of parliament. Feminist Media Studies, 20(5), 692-712.

Le Billon, P., \& Lujala, P. (2020). Environmental and land defenders: Global patterns and determinants of repression. Global Environmental Change, 65(1), 102-163.

Leopeng, B., \& Langa, M. (2020). Destiny overshadowed: masculine representations and feminist implications in a South African men's magazine. Feminist Media Studies, 20(5), 672-691.

Martinez-Alier, J. (2002). The environmentalism of the poor. A study of ecological conflicts and valuation. Edward Elgar.

Martinez-Alier, J. (2013). The environmentalism of the poor. Geoforum, 54(1), 239-241.

Martinez-Alier J. \& O'Connor M. (1996). Ecological and economic distribution conflicts. In Costanza R., Segura O., \& Martinez-Alier J. (eds) Getting down to earth. Practical applications of ecological economics. (pp. 153-183). Island Press.

Martinez-Alier, J., L. Temper, D. Del Bene, \& A. Scheidel, 2016. Is there a global movement for environmental justice? Journal of Peasant Studies, 43(3), 731-755.

Martínez Alier, J., \& Navas. G., 2017. La represión contra el movimiento global de justicia ambiental: algunas ecologistas asesinadas. In Alimonda, H., Toro Pérez, C., \& Martín, F. (Eds.). Ecologia politica 
Latinoamericana. pensamiento critico, diferencia Latinoamericana y rearticulación epistémica, (pp. 29-51). Consejo Latinoamericano de Ciencias Sociales (CLACSO).

Morgan, M. (2017). Women, gender and protest: Contesting oil palm plantation expansion in Indonesia, The Journal of Peasant Studies, 44(6), 1177-1196.

Navas, G., Mingorria, S., \& Aguilar-González, B. (2018). Violence in environmental conflicts: The need for a multidimensional approach. Sustainability Science, 13(3), 649-660.

Paredes, J. (2010). Hilando fino desde el feminismo comunitario. CEDEC y Mujeres Creando Comunidad: La Paz.

Peek, B. (2007). Women in the environmental justice sector: Why is it always white men who speak? Agenda: Empowering Women for Gender Equity, 1(73), 118-125.

Rocheleau, D.E., Thomas-Slayter B. \& Wangari, E. (Eds.) (1996). Feminist political ecology: global perspectives and local experience. Routledge.

Scheidel, A., Del Bene, D., Liu, J., Navas, G., Mingorría, S., Demaria, F., Avila, S., Roy, B., Ertör, I., Temper, L., \& Martínez-Alier, J. (2020). Environmental conflicts and defenders: A global overview. Global Environmental Change, 63(1), 1-13.

Shiva, V. (1994). Close to home: Women reconnect ecology, health and development. Earthscan.

Spivak, G. (2010). Can the Subaltern Speak? Reflections on the history of an idea. Columbia University Press.

Sultana, F. (2020). Political ecology 1: From margins to center. Progress in Human Geography, 37(4), 486504.

Taylor, L., \& Hurley, P. T. (2016). Political ecology of exurbia. Springer.

Temper L., Del Bene D., Martinez-Alier J. (2015). Mapping the frontiers and front lines of global environmental justice: The EJAtlas. Journal of Political Ecology, 22(1), 255-278. https://doi.org/10.2458/v22i1.21108

Temper L., Demaria F., Scheidel A., Del Bene, D. \& Martinez-Alier, J. (2018). The Global Environmental Justice Atlas (EJAtlas): Ecological distribution conflicts as forces for sustainability. Sustainability Science, 13(3), 573-584. https://doi.org/10.1007/s11625-018-0563-4

Temper, L. \& J. Martinez-Alier, J. (2018). Mapping ecologies of resistance. In Horowitz, L., and Watts, M.J. (Eds.), Grassroots environmental governance. Routledge.

Tran, D. (2021a). Women Environmental Defenders coping with silencing and violent repression. Manuscript submitted for publication.

Tran, D. (2021b). Black mothers are willing to die to protect their communities: Sensationalism and silencing of South African women environmental defenders in the media. Manuscript in progress.

UNEP (n.d.). Who are environmental defenders? Retrieved December 21, 2020, from

https://www.unenvironment.org/explore-topics/environmental-rights-and-governance/what-wedo/advancing-environmental-rights/who

Unger, N. (2008). The Role of Gender in Environmental Justice. Environmental Justice, 1(3), 115-120.

Veuthey, S. \& Gerber, J. (2012). Accumulation by dispossession in coastal Ecuador: Shrimp farming, local resistance and the gender structure of mobilizations. Global Environmental Change, 22(1), 611-622.

\section{Appendix: Summaries of EJAtlas cases}

\section{Africa \\ Dian Fossey (Rwanda): Conservation}

Dian Fossey was one of the world's most famous primatologists. On September 24, 1967, she founded the Karisoke Research Center (KRC) within the Volcanoes National Park, which had been seriously threatened by 
illegal mining, land-grabbing, logging, poaching, and agribusiness along with their accompanying violence, deforestation, and pollution. Fossey also advocated against foreign companies' extractivism for environmental degradation and violating Indigenous land rights. She paid for equipment, food, and wages for park staff to encourage them to enforce anti-poaching laws, but felt betrayed by officials complicit in poaching and other injustices behind her back. In retaliation, she used increasingly aggressive tactics drawing much controversy. Death threats multiplied against Fossey before her body was found in her cabin on December 27, 1985. She had been slashed in the head and the inside of her skull was visible. The police investigation was poorly handled. On June 9, 2001, Belgian police captured Protais Zigiranyirazo, who ordered the killings of over 800,000 people during the Rwandan Genocide. He allegedly commanded Fosey's murder because she was about to leak information about gold and animal smuggling rings among Rwandan elites, and for her efforts to restrict poaching. However, Zigiranyirazo was never charged and the case remains open.

\section{Fikile Ntshangase (South Africa): Mining}

Ntshangase was the Vice-Chairperson of a sub-committee of the Mfolozi Community Environmental Justice Organisation (MCEJO) in KwaZuluNatal. On October 22, 2020, after having already narrowly survived a previous assassination attempt, four hitmen shot and killed her in front of her young grandson in her home. It is suspected that the killing was in retaliation for her refusal to sign an agreement with Tendele to cease MCEJO's court challenges against its Somkhele coal mine. These court challenges were for a review of Tendele's new mining rights to expand 222 square kilometres in Mpukunyoni, due for hearing at the high court in March 2021. At the time, Tendele was pressuring 145 families to give up their ancestral land for the expansion, subjecting them to months of violent intimidation including death threats and open fire on one family's home. Days before her assassination, Ntshangase had intended to write an affidavit exposing subcommittee members bribing her to sign the agreement. Police have opened a murder case investigating the incident, which has yet to be resolved.

\section{Ilaria Alpi (Somalia): Waste dumping}

On December 20, 1992, Italian investigative reporter Ilaria Alpi, accompanied by cameraman Miran Krovatin, flew to Somalia to write a story about Italian humanitarian organizations donating money to developing countries for building roads and improving infrastructure. However, Alpi soon discovered that these organizations were fronts for Italian mafia groups (backed by Italian governmental agencies) trading weapons to Somalian warlords for permission to dump toxic waste. In Bosaso, Alpi found, documented, and filmed waste smuggling ships, watching thugs unload toxic waste for burial in the desert. Alpi then began investigating a complex system of arms and waste trafficking involving various warlods, Bosaso's sultan, the Italian-Somali Chamber of Commerce, Italian secret service, and Swiss bankers. On March 20, 1994, Alpi and Krovatin were in Mogadishu to submit their reports at the Italian embassy when they were intercepted by several submachine gun-wielding assassins on an off-road vehicle. Both were shot dead and their documents were never recovered. After public pressure, the Italian Parliament started an inquiry for the murder in January 1998, which concluded that the pair was killed by a bandit in a botched kidnapping and burglary attempt. However, this explanation was widely criticized. Investigators asserted that Alpi was silenced from revealing the arms and waste ring, accusing the Italian secret services of playing a major role in the illegal dumping trade. As of 2019, courts keep rejecting demands for new investigations.

\section{Joan Root (Kenya): Overfishing}

Lake Naivasha is a critical source of livelihood for its human inhabitants, dependent on the fishing economy. In 2000, the fish population collapsed when unlicensed fishing exceeding legal catch limits became problematic. Nature documentary filmmaker Joan Root decided to reform poachers and began her own group called the Task Force, mostly comprised of counter-poachers but also including local police and government officials curbing and patrolling poaching on the whole lake. She paid all the counter-poachers salaries. The expoachers, who knew how other poachers worked and where they would be, would go out onto the lake to round up illegal fishermen. The Task Force was initially effective in eliminating almost all poaching. Problems started 
when one of the main counter-poachers began confiscating poacher boats and selling them for his own profit, taking bribes from some to allow poaching. In January 2005, Root and the Fisheries Department gradually cut support for the Task Force and then shut it down completely, leaving the former poachers angry and destitute. She was carjacked and received threatening text messages until she was eventually shot dead in her home the following year on January 13. It is unknown whether the hitmen were working for those fighting to loosen environmental regulations, unlicensed fishers, former Task Force members, or other enemies opposed to her environmentalism.

Kananwa Sibomana, Ila Muranda, Rachel Masika Baraka (Democratic Republic of Congo): Conservation Virunga National Park is home to some of Africa's richest biodiversity. However, owing to eastern DRC's long history of armed conflict, it is also known as the world's most dangerous conservation project. Many park rangers have been killed while defending Virunga. On April 9, 2018, the deadliest attack in the park's history occurred when six rangers were killed in an ambush near the center of the park. Victims included female rangers Kananwa Sibomana and Ila Muranda. Only a few months later, on May 13, 2018, Rachel Masika Baraka also died at the hospital after being mortally wounded while fighting armed bandits. Many bandit groups are in the area. They are associated with a wide variety of crimes such as poaching, ransom kidnapping, mineral and animal smuggling, and especially illegal logging to make charcoal. The park rangers have made huge strides lowering civilian attacks and contributing to the mountain gorilla's population increase, who may have gone extinct without such efforts. Yet the park's "green militarism" has also led to controversies. Current management emphasizes strict law enforcement, harshly cracking down on poaching, fishing, agriculture, and charcoal production. Most local Indigenous groups lost access to their lands and livelihoods without consent or compensation. Displaced peasants sneak back onto park grounds to obtain survival necessities. Bandit groups take advantage of this situation by forcing them to pay protection and escorting fees as they collect needed materials. Because the armed bandits have trained combat experience, it is much easier for park guards to police the local scavengers than the actual criminals doing more serious resource extraction. A cycle of violence is constantly reinforced because steep fines, arrests, and brutal treatment from park authorities make the locals even poorer and force them to enter the park yet again to get subsistence materials. Feeling marginalized does not stop the local populations from still defending the park, however.

\section{Musu Conteh, unnamed woman (Sierra Leone): Mining}

In 2010, African Minerals Ltd. (AML) formally leased land from the government to mine iron ore near the village of Bumbuna. Despite locals' attempts to resist being moved and refusal of offers to buy their property, AML bulldozed their homes and fields while police shot at the people, forcibly sending them away to a barren wasteland. Villagers protested against AML for land grabbing. AML subsequently sent the police to falsely imprison and beat the villagers. On April 17 and 18, 2012, at the height of tension, a group of 50 women called the "secret society" urged men to stay indoors as they marched through the streets toward the police station carrying green twigs in a peace ritual meant to calm down the violence. The women were shot at, and Musu Conteh and a 28-year-old woman died while 8 others were injured and 29 were arrested. Later that day, a delegation of senior government ministers from Freetown arrived in Bumbuna to calm the situation. A week later after negotiations, AML agreed to a $16 \%$ wage increase, setting minimum wages, and building training centers as well as giving damage compensation to the market women. By October 2013, however, the market women had never received the monetary compensation. They resorted to blockading rail lines out of desperation. The police brutality continued throughout 2013, as officers shot anyone seen as threatening the mine, and AML workers hid the bodies. On November 30, 2015, 142 anonymous villagers filed a lawsuit against AML for its responsibility in causing police violence. The court ruled that African Minerals was not liable. As of 2020, attempts to appeal the decision are still unresolved.

\section{Unnamed woman (Nigeria): Oil refining}

On July 8, 2002, a group of middle-aged women activists known as the Escravos Women Coalition (EWC) led more than 600 women from local Indigenous communities in a ten-day occupation protest at Chevron's main 
oil terminal in Escravos, protesting Chevron's long history of exploitation, landgrabbing, and refusal to compensate or to provide jobs to displaced locals. During the following days, over 1,000 women occupied six oil stations belonging to Chevron. On Wednesday July 10, 2002, two days after the occupation began, about 100 police officers and soldiers armed with assault rifles stormed the terminal to protect the facility. Rapes, beatings, and murder were all tactics that soldiers employed to take down female protesters, with at least one confirmed killing of an unnamed woman and more suspected. After ten days of the blockade, the women signed a memorandum ending the occupation in exchange for the company's promise to provide amenities and to employ locals. The promises are still unfulfilled, however.

\section{Asia}

Aysin Büyüknohutçu (Turkey): Mining

Elderly activist couple Aysin and Ali Büyüknohutçu were environmentalists leading a six-year long campaign against destructive stone and marble quarries in Finike, an agricultural district that suffered adverse environmental effects from the open-pit mining. The couple managed to shut down the Bartu Mermer marble quarry, for which they were victim to constant legal harassment, smear campaigns, and death threats. A month after the court decision taking away the mining license and setting a precedent for future cases taking away other companies' permits, their dogs were poisoned and their property was burned. Two weeks later, on May 10, 2017, the couple was shot dead by a hitman, who was caught and confessed he was hired by an anonymous quarry owner. The lawsuit is still ongoing.

\section{Gerlie Menchie Alpajora (Philippines): Overfishing}

In Bicol, fish populations have been decimated by decades of overfishing. Consequently, fishermen catch increasingly smaller fish, restricted species, go to prohibited zones, and use ecologically destructive, illegal methods violating Section 92 of Republic Act 10654 (banning fishing with explosives, poisons, or electricity). Large trawling boats poach fish at night in areas reserved only for small municipal boats, leaving little left for marginalized legal village fishers and destroying the ocean floor. Mayors often receive millions in bribes to turn a blind eye to illegal fishing. The Sagñay Tuna Fishers Association (STFA) has been monitoring and reporting illegal fishing activities despite widespread hostility. Many association members receive death threats. STFA's secretary, Gerlie Menchie Alpajora, was threatened for a week for her campaigns, as well as for reporting illegal fishing before she was shot dead on July 29, 2015 while sleeping beside her two young sons at home. She was killed just after her reports led to the arrest of several illegal fishers. Death threats against other members of the STFA continued after her assassination. Although a case was filed against a possible suspect, police inaction and significant court delays mean that environmental organizations continue to fight for justice to resolve her case.

Gloria Capitán (Philippines): Coal power

Gloria Capitán ("Ate Glo") was a grandmother and karaoke bar owner as well as part of the Philippine Movement for Climate Justice. She was also the leader of the Coal-Free Bataan Movement (CFB) and president of the United Citizens of Lucanin Association. She led her community in a campaign against the open coal storage owned by Limay Bulk and Handling Terminals Inc. located inside the Sea Front Shipyard Port Services compound in Lucanin. Many believe that open coal storage causes the heavy dust storms and severe pollution the community in Bataan is suffering from, causing skin allergies, upper respiratory tract infection, and other health hazards. This has also damaged the coastlines and seabed. Most notably, Capitán led a group of activists demanding the permanent closure of GNPower's Mariveles Power Plant in a context where the local government and national policy hugely favors coal energy and violently represses anyone speaking out. On July 1, 2016, she had been in her karaoke bar with her 8-year-old grandson when two hitmen on motorcycles with bandanas covering their faces shot her once in the arm and twice in the neck. When her family called the police, no one came. Capitán was likely murdered for her opposition to the Mariveles Power Plant. Police investigating Capitan's murder have not been seriously pursuing the shooters, who have never been identified. 
Karunamoyee Sardar (Bangladesh): Aquaculture

Landless peasant Karunamoyee Sardar fought the shrimp industry in Horinkala, one of the largest villages of Polder 22. During the second half of the 1980s, international banks and development agencies began financing projects promoting large-scale commercial shrimp farming in Bangladesh. One of the methods politicians used to grab land from locals was intentionally flooding the area using sluice gates as armed guards stood watch. Villagers had little power to drain the water. Consequently, the flooding devastated their communities by making the subsistence farming they relied on near-impossible owing to soil and groundwater salination. The villagers would often have no choice but to sell their lands to shrimp thugs for extremely low prices, sparking conflicts. Sardar had been leading protests preventing shrimp boss Wajad Ali from opening Polder 22 to the shrimp industry. Previously, most peasant movements defending against shrimp industry intrusion had been unsuccessful. On November 7, 1990, she was shot dead by shrimp goons at a demonstration. Her legacy inspired many of her supporters and fellow anti-shrimp activists to come together in further protesting, resulting in successfully preventing all attempts to bring the shrimp industry into the polder. However, the struggle is far from over, because armed thugs continue to violently repress the activists and threaten them.

\section{Montha Chukaew, Pranee Boonrat (Thailand): Agriculture, Oil Palm}

Montha Chukaew and Pranee Boonrat were both human rights activists for the Southern Peasant's Federation of Thailand (SPFT), defending land rights for the Khlong Sai Pattana community. A palm oil company, Jiew Kang Jue Pattana Co. Ltd., illegally occupied land, displacing peasants over 30 years after their lease expired thanks to government complicity. Attempts have been made to take the company to court for land theft, and the community received Supreme Court support in 2007. Still, the court order failed to expel the private company from the land. Instead, they issued an order to forcibly push the private company and their workers out. Yet no land was redistributed among the peasants and Jiew Kang Jue Pattana sued the government as well as SPFT members. In retaliation to their activism, on November 19. 2012, Chukaew and Boonrat were shot approximately 800 meters from town while going to the market. The Bangkok Post reported that more than 30 environmental defenders have been killed in the country since 2001. Nevertheless, only about one-fifth of the total number of cases have had judicial consequences.

\section{Nasreen Pervin Huq (Bangladesh): Coal mining}

Nasreen Pervin Huq was a masters-educated human rights and women's rights activist for the organizations Action Aid and the Bangladesh Rural Advancement Committee (BRAC). She was well-known for her involvement in many causes, but most notably fought against British company Asia Energy's (a subsidiary of GCM Resources) Phulbari project proposal for an open-pit coal mine and 500MW thermal power plant. The project could have displaced as many as 220,000 people, including tribal groups, because the operations drain away groundwater. Huq had started raising concerns about Asia Energy's plan from February 2006 and had been contacting lawyers from London to collaborate on challenging the company in an international court. Her sister said that Nasreen had been compiling a dossier on the case and was preparing to distribute it to legal contacts and the press. Action Aid at the time had not been very supportive of her efforts owing to concerns that they would lose funding if she continued. Many others such as the UK Department for International Development and the department chief in Dhaka also asked her to drop her campaign. On April 24, 2006, Huq died in a suspicious accident when another car slammed her own into a wall. This was the first of a chain of mysterious deaths during a season of widespread protests that year. The police initially dismissed the case as merely an accident caused by the other driver's foot slipping onto the accelerator instead of the brake. However, Huq's supporters pushed the police to investigate a possible murder. The police kept the driver under investigation as a suspect but did not charge him. On August 26, 2006, 50,000 protesters marched in the streets against the Phulbari coal project, and three people were killed and at least a hundred more were injured by the Bangladesh Rifles, a paramilitary group. Protesters continued to fight despite violent repression for years, until the project was finally abandoned in 2014. 
Shehla Masood (India): Diamond mining

The Chattarpur district of Madhya Pradesh is home to the Panna Tiger Reserve within the Buxwaha forest. This ecosystem has been threatened by transnational British-run Rio Tinto's Bunder Diamond Mine, which as to open in Buxwaha a few kilometers away from the tiger reserve and affecting some of the poorest peoples in the region. One of the first to fight this mine was Shehla Masood, a tiger conservationist and president of the Progressive Muslim Women's Association (PMWA). She received constant death threats, smear campaigns, and harassment for her efforts, particularly those against the Rio Tinto mine. Masood had been working on a legal case against Rio Tinto's illegal operations when, on August 16, 2011, hitman Imran Ali shot Masood in the neck. Masood's father found her body shortly afterward, but suspiciously, no other witnesses confirmed seeing or hearing the shot despite the murder occurring in broad daylight on a busy street. According to the Central Bureau of Investigation (CBI), she was murdered by interior designer Zahida Pervez. Pervez was allegedly driven to insanity over jealousy after seeing Masood negotiating with legislative politician Dhruv Narayan Singh, with whom Pervez imagined herself in an affair. Many people challenged the CBI's conclusion. In 2019, journalist Hemender Sharma uncovered evidence suggesting that the jealousy story was a coverup for Singh trying to eliminate Masood. However, the court decision has not changed and many fear her real assailants will never be apprehended.

Teresita Navacilla (Philippines): Copper and gold mining

Grandmother Teresita Navacilla was part of the Save Pantukan Movement (SPM), a local network fighting for Indigenous land rights. In 1992, Filipino-owned Nadecor and US-owned St. Augustine received rights from the government to explore, develop, and extract materials from their proposed King-King Copper-Gold Project, a large-scale open pit mine in Pankutan. The site is the nation's second largest copper and gold deposit. Yet not only is Pantukan Indigenous territory, but the mining project also seriously threatens marine ecosystems, which are home to 253 highly vulnerable or endangered species. Navacilla had been directly opposing the King-King mine, advocating for stricter policies and denouncing extractivism by foreign corporations. On January 27, 2016, two men on motorcycles entered Navacilla's store in Purok Bardown and shot her dead. It is widely believed they were soldiers of the Infantry Battalion 46, which had been assigned to secure the King-King mining project (Suazo 2016). She died three days later in the hospital. The battalion's commander, Seigfred Tubalado, denied accusations that his soldiers were involved. Yet many residents have reported that the soldiers have arrested and assaulted various Indigenous and civilian groups in the area voicing opposition to the mining project.

\section{Valsa John (India): Coal mining}

Catholic nun Valsa John, from Kerala, who was involved in a movement against displacement of tribal people by coal mining companies in Jharkhand, was shot dead in November 2011. She was a member of the Rajmahal Pahar Bachao Andolan (RPBA), an Indigenous rights organization. The murder happened at Bachuwari village in Pakur district. The police suspect the coal mafia to be behind it. In the immediate context, she had been protesting the functioning of a private coal mine in Pakur district. She was seeking to protect the interests of the Santhal tribe, some members of which were displaced by the Panem Coal Mines. Locals had been protesting the mines and threatening to blockade it until the families were recompensated. However, the case and murder are still unresolved.

\section{Latin America}

\section{Alberta "Betty" Cariño Trujillo (Mexico): Hydropower}

Alberta Cariño, an Indigenous peasant, was the director of CACTUS (Centro de Apoyo Comunitario Trabajando Unidos), a nonprofit in Oaxaca. Most notably, she supported an Indigenous rights movement against a dam megaproject in San Juan Copala. On April 27, 2010, while heading to San Juan Copala to deliver supplies to about 700 Triqui people during their peaceful protest for territorial rights, Cariño and other activists were ambushed by shooters. More than ten people were injured, and Finnish activist Jyri Jaakkola also died 
during the attack. Cariño's husband, her lawyer, and other activists report that authorities have not only been delaying legal processes and investigations, but also been failing to protect witnesses. Many involved in the still pending legal battles have also been receiving threatening phone calls.

\section{Adelinda Gómez Gaviria (Colombia): Mining}

Adelinda Gómez was a mother of three juggling multiple jobs along with anti-mining activism as leader of the Macizo Colombiano Integration Committee (MCIC). Macizo Colombiano is a UNESCO Biosphere Reserve, an important water source for major rivers, and one of Colombia's poorest regions. Nowadays, agribusiness and mining have heavily polluted the area. In 2003, the Mining and Energy Ministry granted 64 mining licenses in the area while many others had fraudulent permits (Proceso Campesino 2009). Mining representatives attempted to gain the communities' goodwill through community parties, giving away branded sportswear, and promising jobs, housing, and reforestation. Wary of the corporations' historical exploitation, however, Gómez contested the mining industry through various resistance activities. In February 2013, Gómez led a protest against companies such as Anglo Gold Ashanti and Continental Gold, denouncing mining's social and environmental impacts. She soon received death threats. On September 30, 2013, she was shot by two hooded hitmen. She died instantly while her 16-year-old stepson was badly hurt. Authorities held a public hearing, but her killers remain unknown and there has been no progress solving the case.

Berta Isabel Cáceres Flores (Honduras): Hydropower

University-educated teacher Berta Cáceres was an Indigenous rights activist for her people, the Lenca, and founder of the Council of Popular and Indigenous Organizations of Honduras (COPINH). In 2010, Honduran company Desarrollos Energéticos S.A. (DESA) got approval to build the Agua Zarca Hydroelectric Project on Lenca territory a few kilometers from a wildlife reserve. This project, four hydroelectric dams on the culturally sacred Gualcarque River, aimed to generate 21.3 MW over 20 years. DESA subcontracted Chinese-owned Sinohydro, which already had a history of land grabbing worldwide, and German company Voith Hydro Holding to build turbines. Despite objections that the work began without prior and informed consent, as the 169 ILO requires in Indigenous territories, construction moved forward as companies violently threatened them and the Lenca were banned from their own water. In retaliation, on April 1, 2013, Cáceres and companions led a blockade on the road to the project site. They demanded the removal of all dam equipment. Protests continued throughout the year as officers forcibly removed protestors from the site. Participants reported frequent threats and harassment from company employees, security guards, and the military, who also shot dead COPINH member Tomás Guardia and injured three others. Escalating conflict caused Sinohydro to cancel their contract and the International Finance Corporation to revoke financing. After years of death threats, hitmen shot Cáceres in her home on March 2, 2016. Attempts to blame her death on COPINH failed and banks withdrew their investments from the dam.

\section{Dorothy Stang (Brazil): Logging}

Originally from Ohio, USA, from 1982, Sister Dorothy Stang worked in Anapu, Pará for the Pastoral Comission for the Earth (CPT), a group of clergy and nuns addressing increased violence resulting from land grabbing for the timber trade on Amazonian Indigenous land. Throughout her mission, Stang tried to persuade local and state governments to protect the peasants. Yet violence escalated as land grabbers hired gunmen to murder anti-loggers. In 2004, Stang went to Brazilia, the capital of the country, to testify in Congress about the deforestation and violence with the support of environmental groups, claiming around 90\% of Pará's timber exports were illegal and named timber companies working in Indigenous territory. Loggers described her as a terrorist and accused her of arming peasants. She and other local leaders received death threats. However, Stang continued to work for peasants' land rights. On February 14, 2006, hitmen assassinated her. Although most crimes against WEDs go unpunished, her murderers were jailed. Of the 1,270 murders from land conflicts in Pará documented by the CPT between 1985 and 2013, less than 10\% went to court. 


\section{Guadalupe "Lupita" Campanur Tapia (Mexico): Logging}

Guadalupe Campanur fought for Indigenous rights of the Cherán community in Michoacán. In 2008, indiscriminate logging exacerbated wildfires destroying 20,000 out of 27,000 hectares of Cherán land. The conflict intensified in 2008 when Roberto Bautista became municipality president and granted logging privileges to drug cartel La Familia Michoacana. Consequently, criminal logging increased violence, extortion, and eviction, destroying livelihoods, and murdering or 'disappearing' any opposition. Environmental consequences included water shortages, wildlife loss, and plant loss including vital medical herbs. Campanur then founded Ronda Comunitaria (RC), an organization of forest rangers protecting the area and demanding the state and federal government for help (but got no responses). On April 15, 2011, local women blocked timber trucks, resulting in a violent confrontation killing two people. The Cherán then switched their mobilization strategy toward reforestation. The government also granted their right to self-determination. Yet they were still threatened. On January 17, 2018, Campanur's naked, raped corpse was found in the forest after she had been missing for days. The case remains unresolved and violence against the Cherán and their land continues.

\section{Jeannette Kawas (Honduras): Conservation}

Accountant Jeannette Kawas was not only a conservationist, but she also fought for Garifuna (Afrodescendant peoples), whose small-scale fishing livelihoods are threatened by industry encroachment, waste contamination, ranchers, and poachers, as well as internal problems from firewood gathering, overfishing, and population pressures. Concerned with threats to the land such as the sugar, palm oil, tourism, livestock, and timber industries, she created the Foundation for the Protection of Lancetilla, Punta Sal, Punta Izopo and Texiguat (PROLANSATE). She was then able to declare Punta Sal and its other neighboring forests as protected national parks. On February 6, 1995, at 7:30pm, Kawas was shot to death in her house. The Inter-American Court of Human Rights (IACHR) officially stated that her murder was directly caused by opposition to her environmental activism against private appropriation of Punta Sal.

\section{Kimberley Blackwell (Costa Rica): Conservation}

Canadian Kimberley Ann Blackwell moved to a farm next to Corcovado National Park in 1993 and started a project with local women called Samaritan Xocolata, making fair-trade sustainable chocolates at double the average wage to empower female workers and give them a pathway to avoiding eco-criminals. Although Corcovado has protected status and Costa Rica has legislation such as the mining code, a biodiversity law, and national parks law, it has not stopped (often wealthy) criminal organizations, miners, smugglers, and poachers from going after its natural resources and using the area for cocaine and human trafficking. Criminals are not only dangerous to wildlife and environment, but also to park rangers, who are subject to daily death threats and violent targeting. In response to criminals trespassing onto her property to infiltrate Corcovado and kill animals she rehabilitated, Blackwell advocated against the ecological and ethical effects of the environmental crimes around the park, for which she was often badly beaten. Once, Blackwell used a toy gun to shoot a poacher in the arm with a plastic bead. Just a few days after the incident and filing numerous complaints against him and other illegal hunters, on February 2, 2011, park rangers found her strangled corpse on the ground outside her house. The investigation remains inconclusive despite pressure on both Costa Rican and Canadian authorities to investigate. Supporters continue fighting against illegal activities, especially hunting, in Corcovado.

\section{Laura Leonor Vásquez Pineda, Merilyn Topacio Reynoso (Guatemala): Mining}

Indigenous Xinca grandmother Laura Leonor Vásquez Pineda ran a small business in San Rafael Las Flores, Santa Rosa when in 2010, Gold Corp sold Tahoe Resources Inc. (both from Canada) silver, gold, lead, and zinc exploration and exploitation licences to start the $40 \mathrm{~km}^{2}$ El Escobal mining project. Vásquez founded the Committee for the Defence of Life and Peace in San Rafael Las Flores (CDVPSRLF), which fought the proposal on the grounds that the Xinca did not consent, and there was possible damage to water sources, land, and people's health unaccounted for in Tahoe Resources' Environmental Impact Analysis (EIA). She led protests, sit-ins, and demonstrations, during which protestors were injured by rubber bullets. During one of the 
demonstrations, on April 27, 2013, an attack left several injured and 16-year-old Merilyn Topacio from the Youth Movement of Mataquescuintla (MJM) dead. Military force suppressed the movement. In 2013, after 250 appeals were filed against the mine, courts suspended Tahoe Resources' license thanks to legal advice from the Guatemala Legal, Environmental and Social Action Center (CALAS). However, the project restarted in 2014 as lawyers and many others associated with the case received constant death threats and were sometimes killed. The mining company hired Grupo Golan as part of its violent security plan against continued protesting, even killing a local farmer in April 2015. On January 16, 2017, Vásquez was fatally shot in the head when hitmen broke into her house. Tahoe Resources later sold the mine to Pan American Silver.

\section{Macarena Valdés (Chile): Hydropower}

Macarena Valdés, an environmental educator, her husband Rubén Collío, a Mapuche environmental engineer, and her children lived in the Newen-Tranguil Indigenous Mapuche community in Liquiñe, where Valdés emerged as a leader teaching environmentalism, defending the territory, and promoting public health. At the time, multinational energy corporation RP Global, with help from regional authorities, was building a hydroelectric dam on the Tranguil River without consent. In response, on August 1, 2016, Valdés blockaded a road where RP Global attempted to install cables. The local governor met with community members and ordered RP Global to leave, though the governor postponed their eviction, making several excuses. On August 21, RP Global came to start construction where Valdés's family had been living, which the family blocked. The day after, Collío found his wife's body hanging in their kitchen. Although her death was registered as a suicide, physicians questioned the autopsy and Collío filed a criminal complaint. The following morning, Collío was retrieving the body when RP Global came and tried to restart construction on the property accompanied by Chilean Special Forces in armored vehicles. Locals resisted with more anger and grief than before. Police violence ensued. Macarena's funeral took place the next day, on August 25. On October 13, the company returned, this time with many more police cars and tanks. Violating the law and previous agreements to leave, they installed the cables anyway. In January 2017, community members delivered a petition demanding a full investigation of the Tranguil hydroelectric project and its role in Macarena's death. Her family has yet to resolve the case or find much legal support, and are continuing to push for justice in Chile.

\section{North America and Europe}

Gladys del Estal (Spain): Nuclear power

Gladys del Estal was a university student and part of the Egia Ecologist Group and Euskadi's Anti-Nuclear Committee (ANC). On June 3, 1979, she and 4,000 fellow activists peacefully protested to celebrate the International Day against Nuclear Energy in Tudela. The Civil Guard raided the event. Civil Guard José Martínez Salas allegedly made an obscene comment toward del Estal, to which she responded with an insult. The officer shot her in the head, and she died on the way to the hospital. Martínez was later sentenced to only 18 months of prison because the court claimed the shooting was an accident. Following her murder, protesters held demonstrations and strikes throughout Euskadi against Spain's plan to build even more nuclear plants in the Basque Coast and along the Ebro riverbank. In 1980, many people gathered to commemorate the anniversary of her death and the International Day against Nuclear Energy with a demonstration. Since then, every year in the Basque Country, people commemorate her death. A few years later, in 1982, there was finally a moratorium on nuclear power plants throughout Spain. The Tudela plant was never built.

\section{Hilda Murrell (United Kingdom): Nuclear power}

Botanist and researcher Hilda Murrell was a prominent member of the Campaign for Nuclear Disarmament (CND) during the 1980s, when anyone associated with the antinuclear movement was under Police Special Branch surveillance, and those probing deeper or known to recruit other protesters were regularly intimidated by MI5. She campaigned against a proposal to build nuclear power plant Sizewell B next to the small, rural fishing village of Sizewell along the coast of Suffolk, a critical ecosystem. When Murrell was in her late 70s, she was scheduled to present a report at a public planning inquiry about the site. Murrell never arrived, however. On March 24, 1984, a local farmer discovered Murrell's body naked from below the waist dumped in a thicket 
of trees nearly 10 kilometers away from her home. An autopsy showed that she was sexually assaulted, beaten, and stabbed before dying from hypothermia. The case remained unsolved for nearly 20 years, during which Sizewell B was eventually completed in 1995. In June 2003, local laborer Andrew George was arrested after advances in DNA and fingerprinting testing technology linked him to the murder. The court closed the case, though various independent investigators claim that they are being intimidated to prevent them from releasing further information challenging what is still widely believed to be a very suspicious case likely covering up secret services involvement.

\section{Jane Tipson (Saint Lucia): Conservation}

British-born Jane Tipson was a restaurant owner, founder of the St. Lucia Animal Protection Society (SLAPS), and co-founder of the Eastern Caribbean Coalition for Environmental Awareness (ECCEA), among a wide variety of other advocacy activities. In 2003, Dolphin Fantaseas proposed a dolphinarium at Pigeon Island National Park, an important ecological, cultural, and historical site. Locals consistently resisted such plans, which would devastate local marine habitats and the livelihoods of over 100 fisher people. Tipson was campaigning against the dolphinarium as well as exposing illegal pilot whale poaching for several months, when she began receiving death threats over the phone. She continued her activism despite continuing threats for the next several weeks. On September 17, 2003, Tipson was ambushed in her car on the way home from work, dying instantly from a gunshot to the neck. Although the assassination is still under investigation, many speculate that it was to silence her activism owing the suspicious circumstances surrounding her death, the unprofessional investigations, as well as the company's violent history. Public opposition and legal action following Tipson's death led to Dolphin Fantaseas losing their permits to build the park in February 2004, but unfortunately, the project was instead taken over by another dubious Mexican company Dolphin Discovery, which activist groups are still fighting.

\section{Karen Silkwood (United States): Nuclear power}

Karen Silkwood was a technician manufacturing plutonium pellets at the Cimarron Fuel Fabrication Site in Oklahoma, owned by the Kerr-McGee Corporation (KMC). On November 5, 1974, a plutonium contamination detector read that she was contaminated with almost 400 times the legal limit. KMC accused Silkwood of contaminating herself to stir trouble. During this time, Silkwood was also investigating how the plant had been breaking federal labor, building, and machine regulations. She collected evidence in a binder also documenting how the management had been illegally selling enough plutonium to make a nuclear bomb to a smuggling ring. After days of threatening phone calls, on November 13, 1974, she arranged to meet New York Times reporter David Burnham that evening. However, she never arrived because of her death in a mysterious car crash. Her binder was missing from the wreckage. An autopsy indicated that not only was she highly contaminated with plutonium, but she had also been drugged with an excessive dosage of sleeping pills. After her death, supporters filed a lawsuit against KMC, which was settled two years later in the Supreme Court for US\$1.38 million, though KMC refused to admit liability. Various witnesses received death threats and were blacklisted from jobs after the incidents. The plant was shut down in 1976 after bankruptcy caused by negative press, investor withdrawals, and fraud convictions.

\section{Kateryna Handziuk (Ukraine): Logging}

Kateryna "Katja" Handziuk was the advisor to the mayor of Kherson as well as a civic activist well-known for exposing corruption among the government and police, publishing her investigations on social media and on MOST, a citizen journalism website she founded in 2012. She received frequent death threats and surveillance because of her activism against illegal logging. Over $40 \%$ of Ukrainian timber is illegally cut, enabled by Ukraine's widespread corruption at every step of the wood supply chain among politicians, forestry officials, and even the Forest Stewardship Council (FSC). On May 27, 2018, arsonists backed by politicians ignited a 600-hectare forest fire at the Oleshky Forest, where logging is legally prohibited, so that they could collect remaining tree trunks for huge profits justified by a legal loophole permitting harvesting wood from nature reserves as long as the trees fell by "accident." Similar incidences continued to occur all around the region of 
Kherson, and Handziuk was determined to investigate and prosecute everyone responsible. On July 31, 2018, hitmen attacked Handziuk outside her apartment on her way to work, pouring a liter of sulfuric acid all over her back. Over $40 \%$ of her body was severely burned. She survived the initial attack and made it to a nearby hospital, where she worked and gave interviews from her bed until dying on November 4. Police investigations were suspiciously unfruitful. Eventually, six men were charged with murder and received lenient prison sentences. Politicians who ordered the killing were not arrested until February 2019, though there is allegedly not enough evidence to charge them. Supporters continue to protest the timber trade as well as government attempts to obstruct justice. 